\title{
Complement C3 Deficiency Leads to Accelerated Amyloid $\beta$ Plaque Deposition and Neurodegeneration and Modulation of the Microglia/Macrophage Phenotype in Amyloid Precursor Protein Transgenic Mice
}

\author{
Marcel Maier, ${ }^{1 \star}$ Ying Peng, ${ }^{1 \star}$ Liying Jiang, ${ }^{1}$ Timothy J. Seabrook, ${ }^{1}$ Michael C. Carroll, ${ }^{2}$ and Cynthia A. Lemere ${ }^{1}$ \\ ${ }^{1}$ Center for Neurologic Diseases, Brigham and Women's Hospital, and ${ }^{2}$ Center for Blood Research Institute for Biomedical Research and Department of \\ Pathology, Harvard Medical School, Boston, Massachusetts 02115
}

\begin{abstract}
Complement factor $\mathrm{C} 3$ is the central component of the complement system and a key inflammatory protein activated in Alzheimer's disease (AD). Previous studies demonstrated that inhibition of $\mathrm{C} 3$ by overexpression of soluble complement receptor-related protein y in an $\mathrm{AD}$ mouse model led to reduced microgliosis, increased amyloid $\beta(\mathrm{A} \beta)$ plaque burden, and neurodegeneration. To further address the role of $\mathrm{C} 3$ in $\mathrm{AD}$ pathology, we generated a complement $\mathrm{C} 3$-deficient amyloid precursor protein (APP) transgenic AD mouse model $\left(A P P ; C 3^{-1-}\right)$. Brains were analyzed at 8,12 , and 17 months of age by immunohistochemical and biochemical methods and compared with age-matched APP transgenic mice. At younger ages (8-12 months), no significant neuropathological differences were observed between the two transgenic lines. In contrast, at 17 months of age, $A P P ; C 3^{-/-}$mice showed significant changes of up to twofold increased total $\mathrm{A} \beta$ and fibrillar amyloid plaque burden in midfrontal cortex and hippocampus, which correlated with (1) significantly increased Trisbuffered saline (TBS)-insoluble $\mathrm{A} \beta_{42}$ levels and reduced TBS-soluble $\mathrm{A} \beta_{42}$ and $\mathrm{A} \beta_{40}$ levels in brain homogenates, (2) a trend for increased $\mathrm{A} \beta$ levels in the plasma, (3) a significant loss of neuronal-specific nuclear protein-positive neurons in the hippocampus, and (4) differential activation of microglia toward a more alternative phenotype (e.g., significantly increased CD45-positive microglia, increased brain levels of interleukins 4 and 10, and reduced levels of $\mathrm{CD} 68, \mathrm{~F} 4 / 80$, inducible nitric oxide synthase, and tumor necrosis factor). Our results suggest a beneficial role for complement $\mathrm{C} 3$ in plaque clearance and neuronal health as well as in modulation of the microglia phenotype.
\end{abstract}

Key words: Alzheimer's disease; amyloid $\beta$; $\mathrm{A} \beta$ peptide; complement; $\mathrm{C} 3$; neurodegeneration

\section{Introduction}

The complement system is essential for immune-mediated defense against pathogens. It may be activated by three pathways: first, via the "classical" activation route through activation of the $\mathrm{C} 1 \mathrm{q}$ complex by Ig/antigen immune complexes or non-immune molecules; second, via the immune-complex-independent alternative activation pathway leading to deposition of $\mathrm{C} 3$ fragments on target cells; and, third, via the lectin route by binding mannose-binding lectin to pathogen-associated molecular patterns (PAMPs) (for review, see Beek et al., 2003). Activation leads to the formation of multimolecular enzymes that cleave and activate the central component $\mathrm{C} 3$. This may lead to the formation of the cytolytic membrane attack complex (MAC), resulting in

\footnotetext{
Received 0ct. 30, 2007; revised April 23, 2008; accepted May 1, 2008.

This work was supported by National Institutes of Health Grant AG20159 (C.A.L.). We thank Guiquan Chen, Admar Verschoor, Diana Li, Eva Luo, Wei Liu, and Weiming Xia for help with experiments, Dan Frenkel for providing some APP mice, and Lennart Mucke for sharing the APP (J20) transgenic mouse line.

*M.M. and Y.P. contributed equally to this work.

Correspondence should be addressed to Dr. Cynthia A. Lemere, Center for Neurologic Diseases, Harvard New Research Building, Room 636F, 77 Avenue Louis Pasteur, Boston, MA 02115. E-mail: clemere@rics.bwh.harvard.edu. M. Maier's present address: Division of Psychiatry Research, University of Zurich, CH-8008 Zürich, Switzerland. D01:10.1523/JNEUROSCI.0829-08.2008

Copyright $\odot 2008$ Society for Neuroscience $\quad$ 0270-6474/08/286333-09\$15.00/0
}

direct lysis of pathogens. Alternatively, coating of complement activating structures (e.g., immune complexes or PAMPs) with complement $\mathrm{Clq}$ activates $\mathrm{C} 3$ byproducts $\mathrm{C} 3 \mathrm{~b}$ and $\mathrm{iC} 3 \mathrm{~b}$ that promote phagocytosis by cells (such as microglia) expressing the corresponding complement receptors (CRs) such as CR1 (CD35), CR3 (CD11b/CD18), or CR4 (CD11c/CD18). Furthermore, the complement system is involved in the production of anaphylatoxins (C3a and $\mathrm{C} 5 \mathrm{a}$ ), modulating inflammation and neuroprotective pathways, clearance of immune complexes, and the regulation of adaptive immunity (van Beek et al., 2003).

In mammals, the liver is the major source of complement proteins, but glial cells as well as neurons express complement proteins during stimulation by inflammatory cytokines (LéviStrauss and Mallat, 1987; Gasque et al., 1995; Thomas et al., 2000). Complement activation plays an essential role in the inflammatory reactions in the nervous system, including in chronic neurodegenerative disorders such as Alzheimer's disease (AD). Complement is fully activated, and complement components, with their corresponding mRNA levels, are upregulated in $\mathrm{AD}$ brains (Eikelenboom et al., 1989; McGeer et al., 1989; Yasojima et al., 1999). Complement components are observed in pyramidal neurons (Shen et al., 1997) and in neurofibrillary tangles and senile plaques in AD brain (Terai et al., 1997; Stoltzner et al., 
2000). Dystrophic neurites are immunopositive for MAC (McGeer and McGeer, 2002) suggesting that MAC may contribute to neuritic dystrophy and neuronal loss in AD.

Complement may have also a protective role in $\mathrm{AD}$ and normal brains, but its role remains controversial. For example, the C5-derived anaphylatoxin, C5a was reported to protect against excitotoxicity in vitro and in vivo (Pasinetti et al., 1996; Osaka et al., 1999). Overproduction of TGF- $\beta 1$ in amyloid precursor protein (APP) transgenic (Tg) mice results in elevated C3 brain levels, increased microglial activation, and reduced amyloid $\beta(\mathrm{A} \beta)$ accumulation (Wyss-Coray et al., 2001). Inhibition of complement activation by transgenic overexpression of the soluble complement receptor-related protein y (sCrry) in APP mice resulted in increased $\mathrm{A} \beta$ accumulation and neuronal degeneration and reduced microglial activation but did not alter total C3 levels in the brain (Wyss-Coray et al., 2002). However, C1q was found to colocalize with fibrillar A $\beta$ in a presenilin 1 (PS1)/APP mouse model (Matsuoka et al., 2001). APP transgenic mice lacking Clq had no change in $\mathrm{A} \beta$ plaque burden compared with $\mathrm{Clq}$ sufficient controls but showed decreased glial activation surrounding plaques and a slowing of neuronal pathogenesis, suggesting a detrimental effect of C1q on neuronal integrity (Fonseca et al., 2004).

Here, we generated an AD mouse model (APP) deficient for $\mathrm{C} 3\left(\mathrm{C}^{-/-}\right)$to study the in vivo role of complement $\mathrm{C} 3$ on $\mathrm{AD}$ pathogenesis. Our results suggest a beneficial role of complement $\mathrm{C} 3$ in $\mathrm{AD}$, particularly with advanced aging and pathogenesis.

\section{Materials and Methods}

Animals. Hemizygous APP transgenic mice (Mucke et al., 2000) [line J20, harboring the (PDGF promoter)-human $\mathrm{APP}_{\text {sw }}$ (K670N, M671L), IN (V717F) transgene; C57BL/6 background] from our breeding colony were bred with homozygous C3-deficient mice $\left(\mathrm{C3}^{-/-}\right)$(Wessels et al., 1995) initially obtained from The Jackson Laboratory (line B6.129S4-C3 ${ }^{\mathrm{tm} 1 \mathrm{Crr}} / \mathrm{J}$; C57BL/6 background) or with C57BL/6 (The Jackson Laboratory). To generate $A P P ; C 3^{-1-}$ animals, $C 3^{-1-}$ mice were bred initially with APP mice, then with $A P P ; C 3^{+/-}$, and later with $A P P ; C 3^{-/-}$mice. Animals were genotyped by PCR with the following primers: $5^{\prime}$ CTTGGGTGGAGAGGCTATTC-3' and 5'-GGTTGCAGCAGTCTATGAAGG-3' for C3 wild-type allele in the same reaction with $5^{\prime}$ AGGTGAGATGACAGGAGATC-3' and 5' ${ }^{\prime}$-ATCTTGAGTGCACCAAGCC-3' for mutated C3 allele; 5'-GGTGAGTTTGTAAGTGATGCC-3' and 5' -TCTTCTTCTTCCACCTCAGC-3' for hAPP allele together with $5^{\prime}$-GCGCGCTCGTGCACACTTATCACA-3' and 5' CTGCCCCTGACTTCCTGGAAGCAC-3' for DNA (GFAP) control. Groups at the different ages were gender balanced and exactly age matched, and the maximal age difference of individual animals within each group was $<1$ month. All animal use was approved by the Harvard Standing Committee for Animal Use and was in compliance with all state and federal regulations.

Plasma and tissue collection. Mice were killed by $\mathrm{CO}_{2}$ inhalation, and blood was collected by cardiac puncture followed by transcardial perfusion with 20-30 ml of PBS as described previously (Maier et al., 2005). The brain was removed and divided sagittally. One hemibrain was fixed for $2 \mathrm{~h}$ in 10\% buffered Formalin, whereas the other hemibrain was snap frozen in liquid nitrogen for biochemical analysis. One hemibrain, one liver, and one kidney were embedded in paraffin as described previously (Lemere et al., 2003).

Brain homogenates and A $\beta$ ELISA. For Tris-buffered saline (TBS) brain homogenates, frozen hemibrains (without cerebellum and brainstem) were homogenized with a Dounce homogenizer in 5 vol of TBS with a protease inhibitor cocktail (Roche Applied Science). The samples were centrifuged at $175,000 \times g$ for $30 \mathrm{~min}$ at $4^{\circ} \mathrm{C}$. The supernatant (TBSsoluble homogenate) was collected and stored at $-20^{\circ} \mathrm{C}$. The pellets were resuspended in the same volume of TBS-T (TBS/1\% Triton X-100 plus protease inhibitor cocktail) buffer, sonicated for $5 \mathrm{~min}$ in $4^{\circ} \mathrm{C}$ water bath, homogenized, and centrifuged at $175,000 \times g$ for $30 \mathrm{~min}$ at $4^{\circ} \mathrm{C}$. The supernatant (TBS-T-soluble homogenate), containing membranebound $\mathrm{A} \beta$, was collected and stored at $-20^{\circ} \mathrm{C}$. The pellets were extracted a third time as described previously (Johnson-Wood et al., 1997) using ice-cold guanidine buffer ( $5 \mathrm{~m}$ guanidine- $\mathrm{HCl} / 50 \mathrm{~mm}$ Tris, $\mathrm{pH} 8.0$ ) (herein referred to as TBS-insoluble or guanidine-soluble homogenate). $\mathrm{A} \beta_{\mathrm{X}-40}\left(\mathrm{~A} \beta_{40}\right)$ and $\mathrm{A} \beta_{\mathrm{X}-42}\left(\mathrm{~A} \beta_{42}\right)$ levels were determined in TBS, TBS-T and guanidine brain homogenates, and total $\mathrm{A} \beta$ in EDTA plasma samples of tail blood. ELISAs specific for human $A \beta_{x-40}, A \beta_{x-42}$, and total $A \beta$ were performed (using antibodies kindly supplied by Elan Pharmaceuticals) according to Johnson-Wood et al. (1997).

C3 and cytokine ELISAs. Plates were coated overnight at $4^{\circ} \mathrm{C}$ with goat anti mouse C3 (1:500; MP Biomedicals) in $50 \mathrm{~mm}$ carbonate buffer, $\mathrm{pH}$ 9.6 , and then blocked for $2 \mathrm{~h}$ in blocking buffer (PBS/1\% BSA). Serum or TBS-brain homogenates were diluted (1:32,000 for serum and straight for brain homogenates) in wash buffer (PBS/0.1\% BSA/0.05\% Tween 20 ), added to the plate for $2 \mathrm{~h}$, hand washed three times, incubated with biotinylated goat anti-mouse C3 antibody (1:1000; MP Biomedicals) in blocking buffer for $1 \mathrm{~h}$, washed, incubated with streptavidin-HRP in blocking buffer for $30 \mathrm{~min}$, washed, and developed with TMB peroxidase substrate for $2-5 \mathrm{~min}$. Stop reagent was added, and optical density was measured at $450 \mathrm{~nm}$. Matching antibody pairs, composed of capture and detection antibodies for murine interleukin-4 (IL-4), IL-10, and tumor necrosis factor $\alpha$ (TNF $\alpha$ ) (BD PharMingen), were used according to the instructions of the manufacturer. Serial dilutions of exogenous cytokine were added as standards. TBS and TBS-T brain homogenates were added to the plate without dilution.

$A P P$, secreted $\alpha A P P$, synaptophysin, C3, inducible nitric oxide synthase, CD68, and F4/80 Western blot. Western blot was performed as reported previously (Peng et al., 2006). TBS-brain homogenates were used to detect secreted $\alpha$ APP ( $\alpha$ APPs), C3, and inducible nitric oxide synthase (iNOS) levels, whereas TBS-T brain homogenates were used to examine total APP, CD68, F4/80, and synaptophysin (SYN) levels. Briefly, samples were denatured in SDS sample buffer and separated on 10-20\% Tricine gels (Invitrogen). Polyclonal antibody R1736, which recognizes residues 595-611 of APP695 (1:1000; gift from D. Selkoe, Center for Neurological Disorders, Boston, MA) was used to specifically detect the $\alpha$-secretase-generated ectodomain fragment of APP. Monoclonal antibody 8E5 (1:1000), which recognizes residues 444-591 of human APP, was used to detect the full-length APP (a gift from Elan Pharmaceuticals). Polyclonal anti-C3 (1:500; MP Biomedicals), anti-synaptophysin (1:1000; Sigma), anti-iNOS (1:200; BD Bioscience), anti-CD68 (1:200; Serotec), anti-F4/80 (1:200; Serotec), and anti- $\beta$-actin (1:10,000; Sigma) were used to probe the membrane. Horseradish peroxidase-coupled anti-rabbit or anti-mouse IgG were used as secondary antibodies. The signal was detected with an enhanced chemiluminescence kit (Pierce). Densitometric evaluation was performed using an imaging system and the corresponding analyzing software (FluorchemTMIS-8800 software; Alpha Innotech). Protein levels were normalized to $\beta$-actin.

Immunohistochemistry. Serial $10 \mu \mathrm{m}$ sagittal paraffin sections of mouse brain were mounted on glass slides, and immunohistochemistry was performed as reported previously (Lemere et al., 2002) using Vector ELITE ABC kits (Vector Laboratories). The following antibodies were used for neuropathological analysis: anti-CD45 (1:5000; Serotec), antiIbal (ionized-calcium binding adapter molecule 1) (1:500; Wako Bioproducts), anti-GFAP (1:500; DakoCytomation), anti-neuronal-specific nuclear protein (NeuN) (1:250; Millipore Bioscience Research Reagents), anti-APP antibody 22C11 (1:200; Millipore Bioscience Research Reagents), rabbit polyclonal anti-A $\beta$ R1282 (1:1000; gift from D. Selkoe), and anti-A $\beta_{40}$ and anti-A $\beta_{42}$ (1:500; BioSource International). Computer-assisted image analysis was used to quantify the percentage area of thioflavin S staining and immunoreactivity as described previously (Maier et al., 2006). Briefly, the percentage area occupied by immunoreactivity was calculated for three to four equidistant sections per animal of total hippocampus area or for one visual field of the whole cortex dorsal to the hippocampus (midfrontal cortex, $\sim 1.5 \mathrm{~mm}^{2}$ ). The threshold for detection of immunoreactivity was kept constant for the analysis of an entire series of sections for each antibody. Presynaptic terminals were labeled with anti-SYN (1:200; Sigma), neuronal cell bod- 
ies and dendrites with anti-MAP2 (1:200; Sigma), and newly generated neurons with anti-doublecortin (C-18, 1:500; Santa Cruz Biotechnology), followed by Alexa488, Rhodamine Red-X (Invitrogen), or cyanine 3 (The Jackson Laboratory) coupled secondary antibodies. To quantify immunoreactivity, acquisition of images was performed in a single session using a SPOT camera with individual red-green-blue channels set for fluorescence (Diagnostic Instruments) and analyzed by NIH ImageJ software.

Stereological neuron counts were performed in three $10 \mu \mathrm{m}$ NeuNstained sagittal brain sections per animal spaced $200 \mu \mathrm{m}$ apart using the optical dissector technique (Irizarry et al., 1997). The average number of neurons per section in the CA3 region of hippocampus was estimated using $\sim 12$ optical dissectors and the Bioquant Image Analysis System according to the principle of Cavalieri (West and Gundersen, 1990). Each optical dissector included a $50 \times 50 \mu \mathrm{m}$ sampling box. Using a $100 \times$ oil-immersion lens, neurons with a visible NeuN cell body were counted if they were not visible in the initial plane of focus but came into focus as the optical plane moved through the tissue. The average number of hippocampal CA3 neurons per section was determined by calculating the mean of the neuron counts from three sections per animal.

Statistical analyses. The Mann-Whitney $U$ test was used for statistical analysis of the percentage area of immunoreactivity in brain sections and $\mathrm{A} \beta$ levels in brain homogenates. The critical $\alpha$ level was set to 0.05 for all statistical analyses. All values reported are average \pm SEM. A two-tailed Spearman's correlation was used for correlation of plaque load and NeuN counts. SPSS software (version 11.5) was used for statistical analysis

\section{Results}

Expression of complement $\mathrm{C} 3$ protein in the $\mathrm{CNS}$ and periphery is absent in C3-deficient APP transgenic $\left(A P P ; C 3^{-/}\right.$ -) mice

To determine the role of central complement component $\mathrm{C} 3$ in $\mathrm{A} \beta$ accumulation and neurodegeneration, we generated APP transgenic mice lacking complement C3 by breeding APP (J20 line) (Mucke et al., 2000) to complement C3-deficient mice (Wessels et al., 1995). Complement C3 gene deletion was confirmed by PCR using primers showing the presence of the mutated allele and the absence of the wild-type C3 allele PCR product in $A P P ; C 3^{-1-}$ mice (Fig. $1 A$ ). Expression of complement $\mathrm{C} 3$ protein was demonstrated by Western blot and C3 ELISA with an anti-C3 antibody in brain homogenates (Fig. $1 B, C$ ) and blood plasma (Fig. $1 D$ ) in 12- and 17-month-old APP mice. In contrast, $\mathrm{C} 3$ protein was undetectable in brain and blood plasma in APP; $C 3^{-1-}$ mice at the same ages (Fig. 1). C3 levels in blood as well as brain were slightly higher in 17-month-old compared with 12month-old APP animals ( $p=0.14 ; n=5$ mice each at 12 and 17 months) and approximately four orders of magnitude higher in plasma than in brain tissue.

\section{Plaque load and gliosis are unaltered in 12-month-old complement C3-deficient APP Tg mice}

To study the role of C3 deficiency on the onset of plaque pathology, we analyzed total $A \beta$ immunoreactive plaque load in the hippocampi of 8 -month-old APP and APP;C $3^{-1-}$ mice $(n=5$ mice per group). Quantitative image analysis showed no significant difference in plaque burden between the groups (data not shown). Semiquantitative analysis of CD45-specific immunoreactivity as a marker for activated microglia and GFAP-specific immunoreactivity as a measure to quantify astrogliosis in the hippocampus revealed no major differences between the groups (data not shown).

At 12 months of age, quantitative image analysis of brain sections stained with $A \beta_{42^{-}}, \mathrm{A} \beta_{40^{-}}$, or pan-A $\beta$-specific R1282 antibodies revealed no significant differences in plaque load in hip-

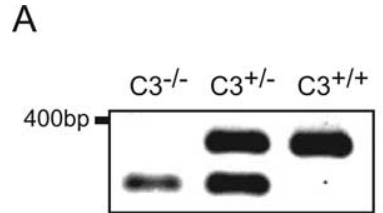

B
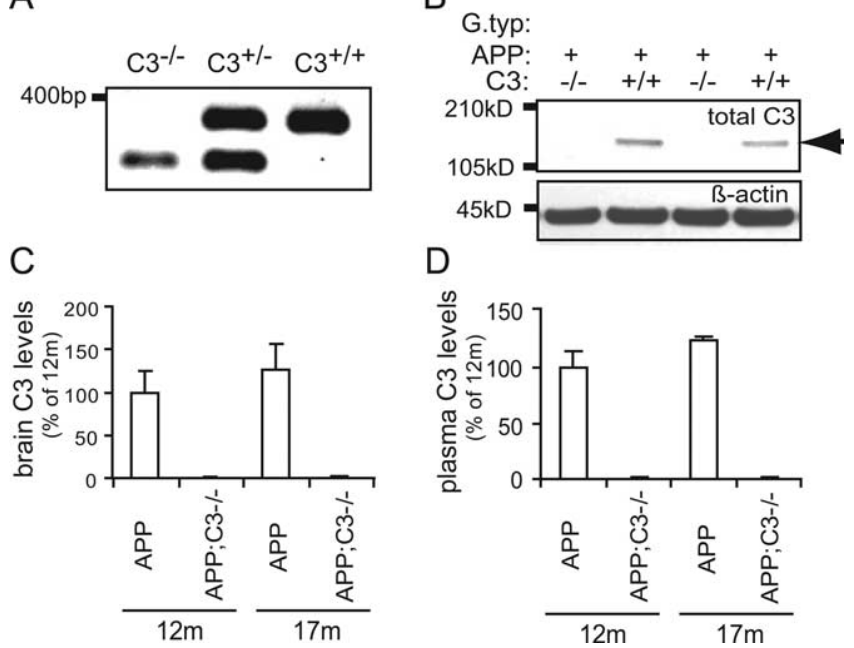

$\mathrm{D}$

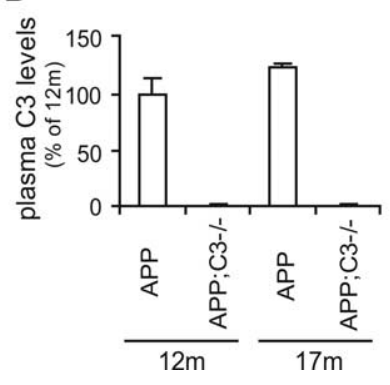

Figure 1. Complement $C 3$ protein is expressed in the brain and in the plasma of 12- and 17-month-old APP mice but is undetectable in APP; $\left(3^{-1-}\right.$ mice. $A$, Complement $C 3$ gene deletion was determined by $P C R$ by the absence of the wild-type $C 3$ allele PCR product (top band at $\sim 350 \mathrm{bp}$ ) and the presence of the mutated allele (bottom band at $\sim 280 \mathrm{bp}$ ). $\boldsymbol{B}-\boldsymbol{D}$, Expression of complement $C 3$ protein in the brain $(\boldsymbol{B}, \boldsymbol{C})$ and plasma $(\boldsymbol{D})$ of 12- and 17-month-old APP mice ( $n=5$ per group) was shown by Western blot $(\boldsymbol{B}, \boldsymbol{C})$ and C3 ELISA (D). C3 protein was absent in the corresponding $A P P ; C 3^{-/-}$mice. The $\alpha / \beta$ dimer of $C 3$ protein $(\sim 185 \mathrm{kDa})$ in brain is indicated by the arrow in $\boldsymbol{B}$.

pocampus or midfrontal cortex in $A P P ; C 3^{-1-}$ mice $(n=8)$ compared with their age-matched APP controls $(n=6)$ (Fig. $2 A, B)(11.8 \pm 2.0$ vs $10.2 \pm 0.9 \%$ area of hippocampus for $\mathrm{R} 1282 ; p>0.05)$. At this age, thioflavin S-positive plaques were mainly detected in the hippocampus, and, again, quantitative image analysis showed no significant differences between the two groups of mice (Fig. 2C). In parallel, no significant differences were found for CD45- and GFAP-specific immunoreactivity (Fig. $2 D, E)$. Quantification of $\mathrm{A} \beta_{42}$ and $\mathrm{A} \beta_{40}$ by ELISA in TBS, TBS-T, and guanidine- $\mathrm{HCl}$ brain extracts also showed no significant differences in $\mathrm{A} \beta$ levels (Fig. $2 F, G$ ). Total $\mathrm{A} \beta$ levels in plasma were increased by $31 \%$, but the difference did not reach significance because of variability (Fig. $2 H)(n=6$ per group; $p=0.11)$.

\section{$\mathrm{A} \boldsymbol{\beta}$ deposition and insoluble $\mathrm{A} \boldsymbol{\beta}_{42}$ brain levels are significantly elevated, whereas TBS-soluble $A \beta$ levels are decreased in 17-month-old complement C3-deficient APP Tg mice}

In contrast to 12 -month-old mice, total $A \beta$ plaque load at 17 months of age was approximately doubled in both the hippocampus and midfrontal cortex in $A P P ; C 3^{-1-}$ mice compared with APP mice as shown by $\mathrm{A} \beta_{42}$ and $\mathrm{A} \beta_{40}$-specific immunoreactivity (Fig. $3 A, B$ ), general $\mathrm{A} \beta$ immunolabeling (Fig. $4 A, B, G, H$, R1282 antibody), and thioflavin S-positive staining of fibrillar amyloid deposits (Figs. $3 C, 4 M, N)(p<0.05 ; n=5$ mice per group). Guanidine-soluble (TBS-T-insoluble) $\mathrm{A} \beta_{42}$ and $\mathrm{A} \beta_{40}$ levels were higher in $A P P ; C 3^{-/-}$mice compared with APP mice (Fig. $3 D, E$ ) at 17 months of age, although only the difference in $\mathrm{A} \beta_{42}$ levels reached significance $(p<0.01)$. These data are in agreement with the corresponding $\mathrm{A} \beta_{42}$ and $\mathrm{A} \beta_{40}$ plaque loads. In contrast, TBS-soluble $\mathrm{A} \beta_{42}$ and $\mathrm{A} \beta_{40}$ levels were significantly lower in APP;C3 ${ }^{-/-}$mice compared with APP mice (Fig. $3 D, E$ ) $(p<0.05)$. TBS-T soluble $\mathrm{A} \beta_{42}$ and $\mathrm{A} \beta_{40}$ levels were nonsignificantly reduced in the APP;C $3^{-/-}$mice compared with APP mice. Total A $\beta$ levels in plasma were increased by $51 \%$ in $A P P ; C 3^{-/-}$ mice compared with APP mice (Fig. $3 F$ ) (nonsignificant trend, 
$p=0.06)$. These results indicate that a deficiency of the key complement factor C3 results in greater accumulation of insoluble $A \beta$ in the brain and a trend for more soluble $\mathrm{A} \beta$ in the plasma with aging in APP Tg mice.

\section{Microglia/macrophage are differentially activated in the brain of complement C3-deficient APP Tg mice toward a more alternative $\mathrm{M} 2$ activation phenotype}

Activation of microglia, measured by CD45-specific immunoreactivity, was significantly increased in hippocampus $(p<$ $0.01)$ and cortex $(p<0.05)$ of $A P P ; C 3^{-/-}$ mice (Figs. $4 C, D, 5 A$ ). Because CD45 staining was associated mainly with compacted plaques and correlated well with thioflavin S-positive plaque load ( $r=0.75$; $p<0.05$; $n=5$ mice per group), we calculated the CD45/thioflavin S ratio as an indicator for activation of microglia corrected by the difference in plaque load (as performed by Wilcock et al., 2006). A trend for an increased CD45/thioflavin S ratio was observed in the hippocampus of $A P P ; C 3^{-1-}$ mice compared with APP mice $(p=0.10)$ (Fig. $5 B)$ even after correction for plaque load.

To further characterize the microglial phenotype, we used anti-Iba1 immunoreactivity and Western blot levels of CD68 and F4/80 as additional markers of microglia/ macrophage activity. Western blot was used because immunohistochemistry with antiCD68 and anti-F4/80 was unsuccessful on paraffin sections. In hippocampus and cortex, Ibal immunoreactivity was detected mainly in microglia/macrophages associated with compacted plaques, but it also stained cells not directly associated with plaques, particularly in the cortex. The number of Iba1-positive cells was somewhat higher in $A P P ; C 3^{-1-}$ compared with APP mice (Fig. $4 I, J)$, but quantitative image analysis revealed no significant differences in the percentage area of Iba-1 immunoreactivity between the two groups (Fig. $5 C$ ). In contrast to CD45 and Iba1, quantification of CD68 and F4/80 microglia/macrophage markers in TBS-T total brain homogenate by Western blot revealed reduced levels of each in $A P P ; C 3^{-/-}$compared with APP mice, suggesting a differential regulation of microglia, but the difference was not statistically significant. No differences in CD68 and F4/80 levels were observed in 12-month-old APP; $C 3^{-1-}$ mice compared with APP mice (data not shown).

Next, iNOS, TNF, IL-4, and IL-10 levels, as indicators of microglia/macrophage phenotype, were examined. iNOS levels in TBS-soluble brain homogenates were significantly lower by

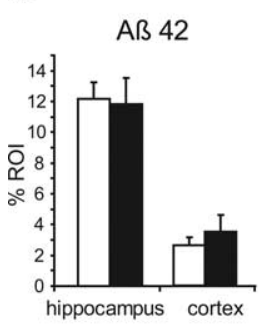

B

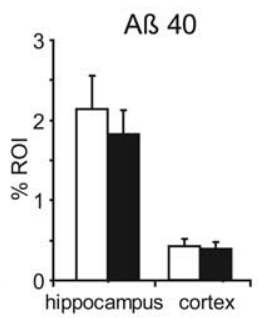

C

D
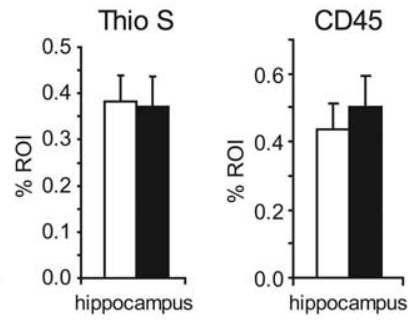

E

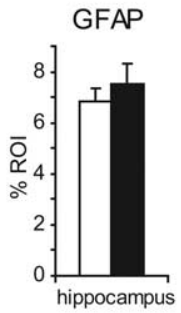

$\mathrm{H}$

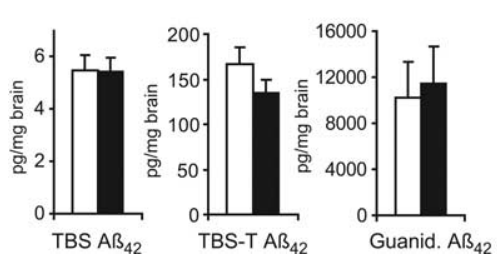

G

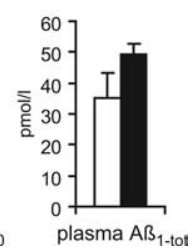

Figure 2. Neuropathological and biochemical analysis at 12 months of age showed no significant differences in plaque load microgliosis, and astrocytosis in $A P P ;\left(3^{-/-}\right.$(filled bars; $\left.n=8\right)$ compared with age-matched APP control mice (open bars; $n=$ 6). $\boldsymbol{A}, \boldsymbol{B}$, Quantitative image analysis of $A \beta_{42^{-}}(\boldsymbol{A})$ and $A \beta_{40^{-}}(\boldsymbol{B})$ specific immunoreactivity did not show any significant differences in hippocampus or midfrontal cortex. $\boldsymbol{C}-\boldsymbol{E}$, Image analysis of thioflavin S-positive plaque load ( $\boldsymbol{C}$ ) as well as CD45- and GFAPspecific immunoreactivity in the hippocampus $(\boldsymbol{D}, \boldsymbol{E})$ revealed no significant differences between the $\mathrm{APP}$ and $A P P ;\left(3^{-1-}\right.$ groups. $\boldsymbol{F}-\boldsymbol{H}$, Quantification of $\mathrm{A} \beta_{42}$ and $\mathrm{A} \boldsymbol{\beta}_{40}$ by ELISA in TBS, TBS-T, and guanidine extracts of brain homogenates $(\boldsymbol{F}, \boldsymbol{G})$ or in plasma $(\boldsymbol{H})$ did not reveal any significant difference between the groups. \% ROI, Percentage of immunoreactivity within the region of interest.
A

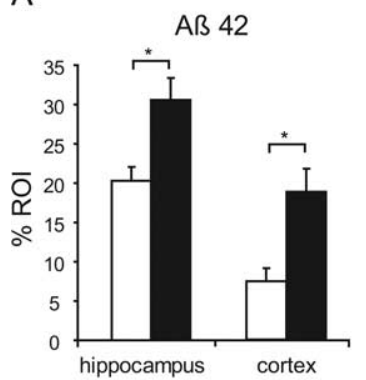

B

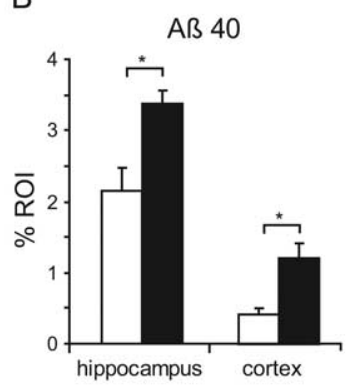

C

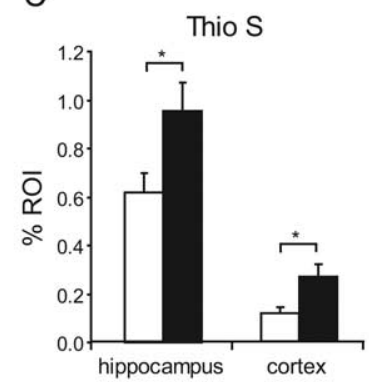

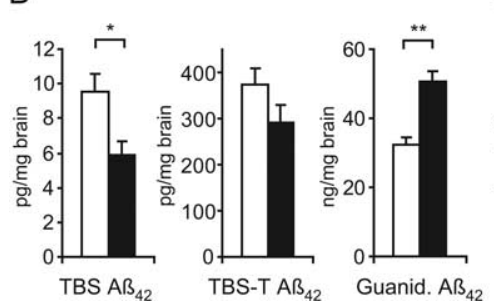

E $\square$ APP $\square$ APP;C3-/-

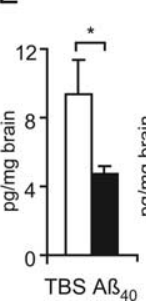

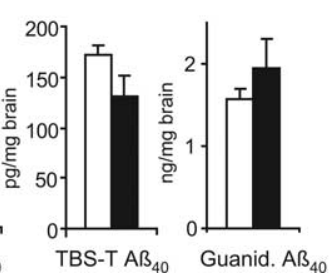

F

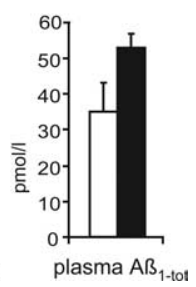

Figure 3. $\boldsymbol{A}-\boldsymbol{E}$, Quantitative neuropathological analysis $(\boldsymbol{A}-\boldsymbol{C})$ and biochemical analysis of brain homogenates by quantitative $A \beta_{42}$ and $A \beta_{40}$-specific ELISAs ( $D, E$ ) of 17-month-old mice shows significantly higher $A \beta$ plaque load and significantly higher $A \beta_{42}$ levels in guanidine brain extract in $A P P ;\left(3^{-1-}\right.$ mice (filled bars; $\left.n=5\right)$ compared with age-matched APP controls (open bars; $n=5$ ). $A-C, A \beta_{42^{-}}$ and $A \beta_{40}$-specific immunoreactivity $(\boldsymbol{A}, \boldsymbol{B})$, as well as thioflavin $S$-positive staining $(\boldsymbol{C})$, were significantly increased in hippocampus and midfrontal cortex of $A P P ;\left(3^{-1-}\right.$ mice $(\boldsymbol{A}-\boldsymbol{C} ; p<0.05) . \boldsymbol{D}, \boldsymbol{E}, A \beta_{42}$ and $A \beta_{40}$ levels in TBS-soluble extracts of brain homogenates were significantly reduced, whereas $A \beta_{42}$ was significantly elevated and $A \beta_{40}$ nonsignificantly increased in TBS-insoluble guanidine extracts in $A P P ; C^{-/-}$mice. $A \beta_{42}$ and $A \beta_{40}$ levels in the membrane-bound TBS-T extracts were nonsignificantly reduced. $\boldsymbol{F}, A$ trend was evident for higher total $A \beta$ levels in plasma samples from $A P P, C 3^{-/-}$mice compared with APP mice $(51 \%$ increase; $p=0.06) .{ }^{*} p<0.05,{ }^{* *} p<$ 0.01. \% ROI, Percentage of immunoreactivity within the region of interest.

Western blot in $A P P ; C 3^{-1-}$ mice compared with APP mice (Fig. $6 A)(p<0.05)$. TBS-T-soluble, membrane-bound TNF levels were significantly reduced $(p<0.05)$ by ELISA, whereas TBSsoluble TNF levels showed a strong trend for reduction $(p=$ 

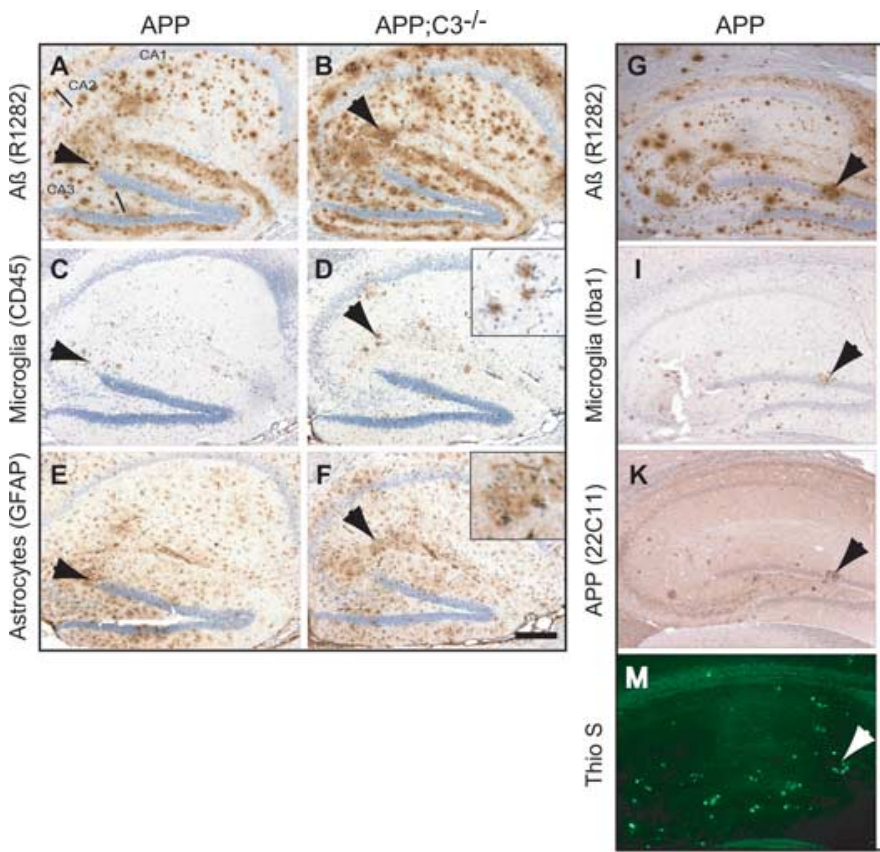

Figure 4. $A-N$, Immunohistochemical analysis of hippocampus of representative sections of 17-month-old APP (left column 2 sets of serial sections: $\boldsymbol{A}, \boldsymbol{C}, \boldsymbol{E}$ and $\boldsymbol{G}, \boldsymbol{I}, \boldsymbol{K}, \boldsymbol{M})$ and $A P P ;\left(3^{-/-}\right.$(right column; 2 sets of serial sections: $\boldsymbol{B}, \boldsymbol{D}, \boldsymbol{F}$ and $\left.\boldsymbol{H}, \boldsymbol{J}, \boldsymbol{L}, \boldsymbol{N}\right)$ mice. $A, B$, Relative to complement-sufficient APP Tg mice $(\boldsymbol{A})$, the total plaque load demonstrated using the pan-specific $A \beta$ antibody R1282 was increased in the complement-deficient $A P P ; C 3^{-1-}$ mice $(\boldsymbol{B}) . \boldsymbol{C}, \boldsymbol{D}$, In parallel, the number of $C D 45$-positive microglia was also increased in $A P P ; C^{-1-}$ mice, and the microglia were mostly associated with compacted plaques (arrows). E, F, GFAP immunoreactivity, a marker for astrogliosis, was comparable between both groups, although modest increases were observed in $A P P ;\left(3^{-/-}\right.$mice. $\mathbf{G}-\boldsymbol{N}$, In parallel to the increase of total $(\mathbf{G}, \boldsymbol{H} ; \mathrm{R} 1282$ antibody) and fibrillar, compact plaque load $(\boldsymbol{M}, \boldsymbol{N} ;$ thioflavin S), the number of Iba1-immunoreactive microglia/macrophage $(\boldsymbol{I}, \boldsymbol{J})$ and dystrophic neurites $(\boldsymbol{K}, \boldsymbol{L})$ observed in APP; $\mathrm{C}^{-1-}$ mice (right column) was increased compared with that of APP mice (left column). Scale bars, $200 \mu \mathrm{m}$.

0.05) (Fig. 6B). A significant increase in IL-4 was observed by ELISA in TBS-soluble brain homogenates in $A P P ; C 3^{-/-}$compared with APP mice (Fig. 6C) $(p<0.05)$. IL-10 levels in both TBS-soluble and TBS-T-soluble brain homogenates were elevated in $A P P ; C 3^{-1-}$ mice compared with APP mice (Fig. 6D), although the differences did not reach statistical differences because of a high level of variability among the mice in each group. Together, these results are indicative of a shift of the microglia/ macrophage toward a more alternative M2 activation phenotype in $A P P ; C 3^{-/-}$mice compared with APP mice (Mantovani et al., 2004; Morgan et al., 2005).

GFAP immunoreactivity of astrocytes in the hippocampus (Fig. $4 E, F$ ) and cortex was nonsignificantly increased in $A P P$; $\mathrm{C}^{-/-}$compared with APP mice (Fig. 5D).

\section{APP processing is not altered in complement C3-deficient APP Tg mice}

To determine whether altered plaque pathology is attributable to altered expression or processing of APP protein, total APP protein levels and $\alpha$ APPs fragments were quantified in brain homogenates by Western blot and normalized to $\beta$-actin levels (Fig. 7) (average of two experiments, $n=4$ mice per group). Total APP levels were slightly increased in $A P P ; C 3^{-/-}$mice at 12 months of age (Fig. $7 A$ ), but, in general, APP levels were not significantly different between the two lines of mice at either 12 or 17 months of age. No differences were observed in $\alpha$ APPs levels between the two groups at either 12 or 17 months, indicating that there was no obvious effect of C3 deficiency on APP processing (Fig. 7C,D).

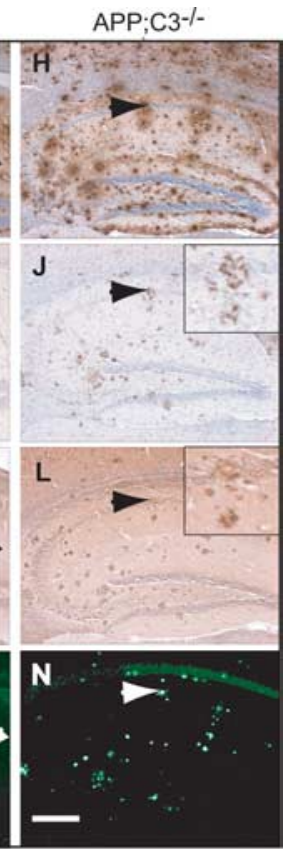

NeuN-positive neurons are reduced in the CA3 region of hippocampus in 17month-old complement C3-deficient APP Tg mice

Anti-NeuN is a neuronal marker that labels most differentiated neurons in the adult neocortex (Mullen et al., 1992), but degenerating neurons seem to lose this marker (Larsson et al., 2001). Consequently, the amount of NeuN-positive neurons was used as a marker to determine the role of complement $\mathrm{C} 3$ on neuronal survival. The average number of NeuNpositive neurons per section (based on three $10 \mu \mathrm{m}$ sections) in the CA3 region of hippocampus, determined by stereological counting, was similar between 12-monthold APP and APP;C3 ${ }^{-/-}$mice (Fig. $8 C$ ) $(221 \pm 8$ vs $225 \pm 5 ; n=6$ mice per group). In contrast, at 17 months of age, the average number of $\mathrm{NeuN}$-positive neurons per section in the CA3 region of hippocampus was significantly reduced in $A P P ; C 3^{-1-}$ mice $(201 \pm 8)$ compared with APP mice $(225 \pm 8 ; p<0.05)$ (Fig. $8 A-C$ ). Furthermore, the average number of NeuN-positive neurons per section was significantly reduced in 17 -month-old versus 12 -month-old $A P P ; C 3^{-/-}$mice ( $p=0.015)$ but not in C3-sufficient APP mice. The average number of NeuNpositive neurons per section within individual mice was inversely correlated with the thioflavin S plaque load (Fig. 8D) $(r=$ $-0.636 ; p<0.05 ; n=5$ mice per group). There was a more pronounced loss of neurons in the CA3 compared with the CA1 region of the hippocampus (data not shown). This may correlate with the observation of an increased expression of the hAPP protein (Fig. $4 K, L$ ) and increased $\mathrm{A} \beta$ plaque load (Fig. $4 A, B, G, H$ ) in $\mathrm{CA} 3$ compared with CA1 in the hippocampus of this mouse model.

MAP2 immunoreactivity, a marker for neuronal dendrites and cell bodies, was slightly reduced in $A P P ; C 3^{-/-}$mice compared with APP mice, but the difference was not significant (Fig. $8 E$ ). Synaptophysin is used as a marker to assess presynaptic terminals and neuronal integrity. Similar to MAP2, no significant difference was observed in synaptophysin staining intensity in the CA1 and CA3 region of hippocampus in brain sections between the two groups (data not shown). Synaptophysin levels, quantified by Western blot of TBS-T brain homogenates, were similar between APP and $A P P ; C 3^{-1-}$ mice at 12 months of age (data not shown) but showed a tendency to be lower in $A P P ; C 3^{-1-}$ compared with APP mice at 17 months of age; however, this difference was not significant (Fig. $8 F$ ).

A reduction of neuronal numbers might possibly be attributable to a reduction in neurogenesis, especially because it was reported recently that complement $\mathrm{C} 3$ and its receptor $\mathrm{C} 3 \mathrm{aR}$ play a role in basal and ischemia induced neurogenesis (Rahpeymai et al., 2006). Neurogenesis usually takes place in the subventricular zone (SVZ) and in the granular cell layer (GCL) of the dentate gyrus (for review, see Lledo et al., 2006). Therefore, we used Doublecortin (DCX) as a marker for newly generated neurons and quantified DCX staining in the SVZ and GCL. Quantification of 
A

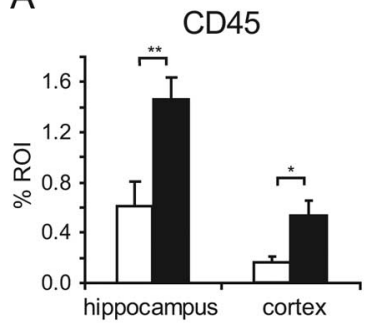

C

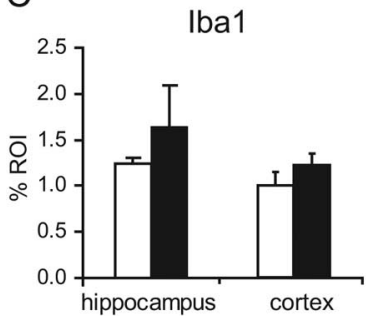

E

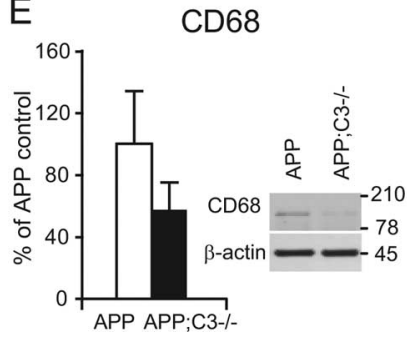

B

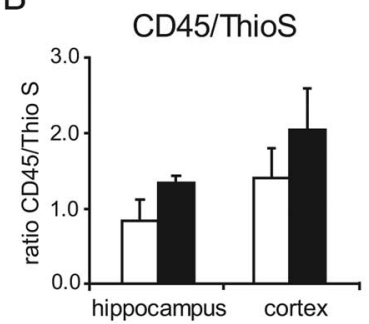

D

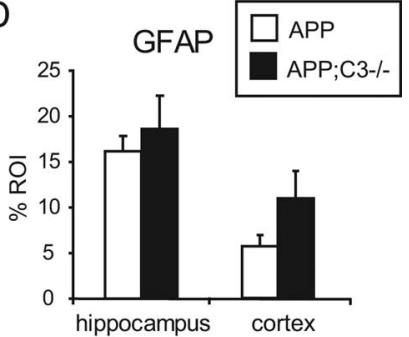

$\mathrm{F}$

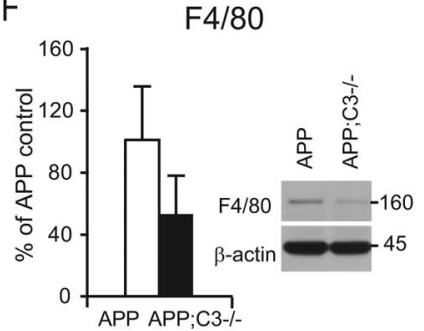

Figure 5. Quantitative neuropathological and biochemical analysis of gliosis at 17 months of age. $\boldsymbol{A}, \boldsymbol{B}$, Total $\mathrm{CD} 45$ immunoreactivity was significantly increased in $A P P ; C^{-1-}$ mice $(\boldsymbol{A}$; $\left.{ }^{*} p<0.05,{ }^{* *} p<0.01\right)$, whereas the CD45/thioflavin $S$ ratio $(\boldsymbol{B})$ only showed a trend to be elevated in $A P P ; C 3^{-/-}$mice $(p=0.10)$. C, Iba1 immunoreactivity was modestly and nonsignificantly elevated in $A P P ; C 3^{-1-}$ compared with APP mice. D, GFAP immunoreactivity was only slightly higher in $A P P ; C 3^{-1-}$ compared with APP mice, but the difference was nonsignificant. $\boldsymbol{E}, \boldsymbol{F}$, In contrast to $\mathrm{CD} 45$ and Iba 1, the levels of microglial markers $\mathrm{CD} 68$ and F4/80 by Western blot were nonsignificantly lower in TBS-soluble brain homogenates of $A P P ; C^{-1-}$ compared with APP mice. The levels in the $A P P ;\left(3^{-1-}\right.$ mice are presented as a percentage of the levels in the APP transgenic mice. $\beta$-Actin was used as a protein loading control.

DCX-positive cells in the GCL, the potential source of new neurons in the hippocampus, was not possible as the labeling of DCX-positive cells in the GCL of 12- and 17-month-old APP or $A P P ; C 3^{-/-}$mice was below the limit of detection unlike the clusters of DCX-positive cells in the SVZ. This finding is in agreement with previous studies characterizing neurogenesis in this animal model (Jin et al., 2004), showing very low levels of neurogenesis in the GCL.

\section{Discussion}

To experimentally address the role of complement $\mathrm{C} 3$ in the pathogenesis of $\mathrm{AD}$, we generated C3-deficient APP transgenic mice and analyzed them neuropathologically and biochemically at 8,12 , and 17 months of age, comparing them with agematched APP transgenic mice. At younger ages ( 8 and 12 months), no significant differences were observed between APP and $A P P ; C 3^{-1-}$ mice in plaque load, biochemical levels of $A \beta$, or any of the neuronal or glial markers examined. In contrast, at 17 months of age, the $A P P ; C 3^{-1-}$ mice showed a significant approximate twofold increase in total $\mathrm{A} \beta$ and fibrillar amyloid plaque burden that correlated with significantly increased guanidinesoluble $\mathrm{A} \beta_{42}$ levels and reduced TBS-soluble $\mathrm{A} \beta_{42}$ and $\mathrm{A} \beta_{40}$ in brain homogenates, a nonsignificant trend for increased plasma

A

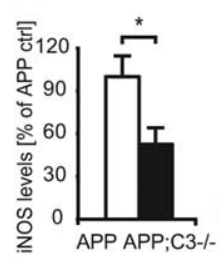

C

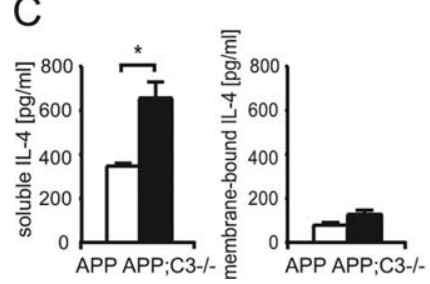

B

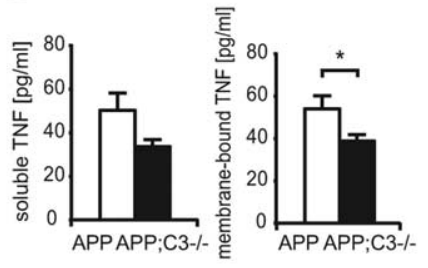

D

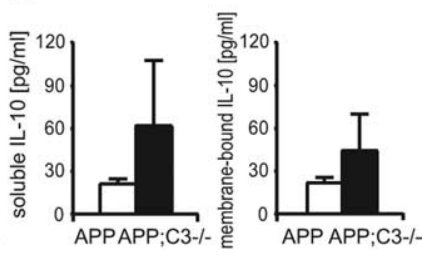

Figure 6. Differential activation of microglia/macrophage in the brains of $A P P ; C^{-/-}$mice toward a more alternative activation/M2 phenotype. $A$, iNOS levels were significantly reduced in TBS-soluble, but not TBS-T-soluble, membrane-bound brain homogenates by Western blot in $A P P ;\left(3^{-1-}\right.$ compared with APP mice $\left({ }^{*} p<0.05\right) . B$, TBS-T-soluble, membrane-bound and TBS-soluble TNF levels by ELISA were lower in APP; $\left(3^{-/-}\right.$compared with APP mice, but only the difference in membrane-bound TNF reached significance $\left({ }^{*} p<0.05\right)$. C, D, IL-4 (C) and IL-10 (D) levels in TBS and TBS-T brain homogenates by ELISA were elevated in APP; $\mathrm{C}^{-1-}$ compared with APP mice, but only the difference in IL-4 in TBS-soluble brain homogenates reached significance $\left({ }^{*} p<0.05\right)$.
A

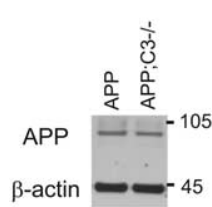

12 months

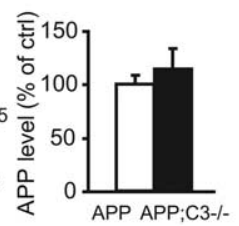

C
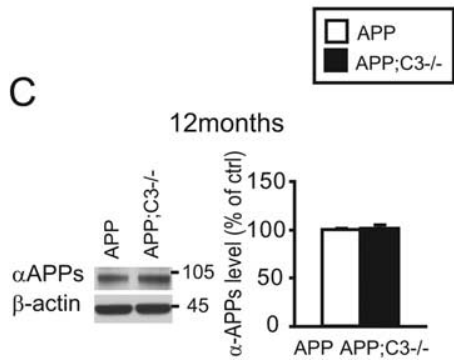

B

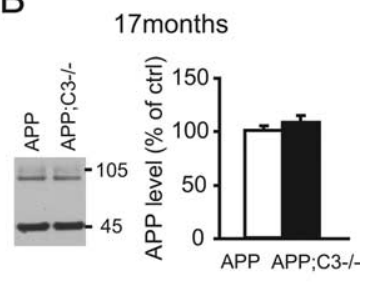

D

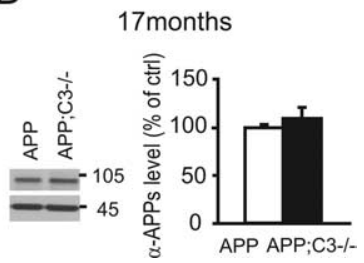

Figure 7. APP processing was not altered in (3-deficient APP mice (filled bars) at either 12 or 17 months of age. Quantification of $\beta$-actin normalized total APP protein $(A, B$; average of 2 experiments, $n=4$ mice per group) and $\alpha$ APPs fragment ( $C, D$; average of 2 experiments, $n=$ 4 mice per group) in brain homogenates by Western blot revealed no difference in protein levels $(p>0.05)$.

$A \beta$ levels, a significant reduction of NeuN-positive neurons in the CA3 region of the hippocampus, and a shift of microglia/ macrophage toward a more alternative activation/M2 phenotype (according to Mantovani et al., 2004; Morgan et al., 2005). Our findings demonstrate that the complete absence of the central complement component, $\mathrm{C} 3$, accelerates $\mathrm{AD}$-like plaque pathology with aging once plaque pathogenesis is underway. Although many of the differences between the APP;C $3^{-/-}$and APP mice reported here were statistically significant, many comparisons resulted in a nonsignificant trend attributable to the relatively small number of mice studied and the high variability observed in 

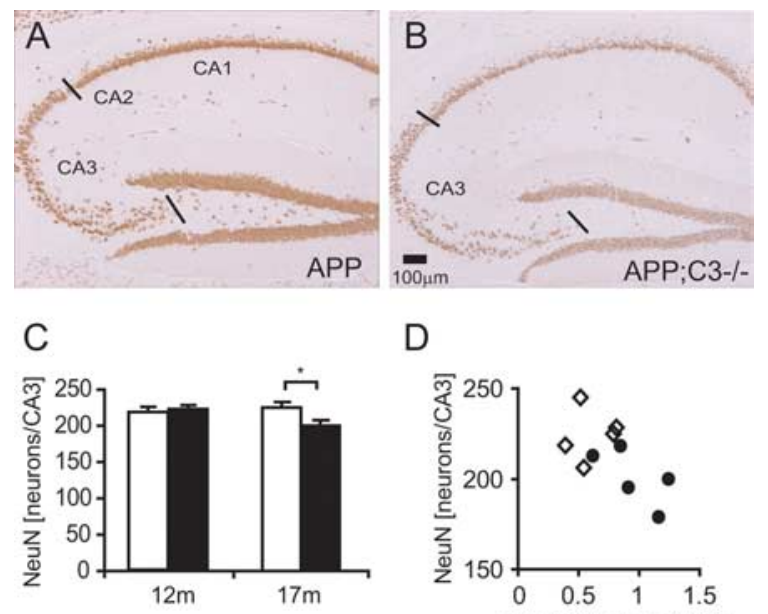

D

E
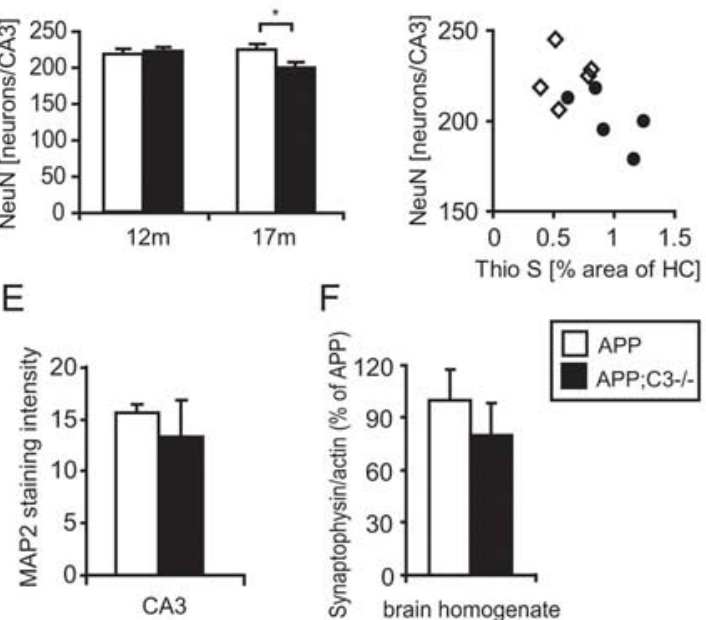

$F$

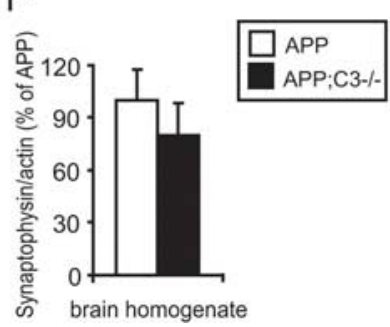

Figure 8. At 17 months of age, C3-deficient APP transgenic mice showed a reduction in the number of NeuN-positive neurons that correlated with the thioflavin $S$ plaque load. $\boldsymbol{A}, \boldsymbol{B}$, Seventeen-month-old $A P P ;\left(3^{-/-}\right.$mice $(B ; n=5)$ had fewer NeuN-positive neurons in the CA3 region of the hippocampus compared with the APP control group $(\boldsymbol{A} ; n=5)$. Neuronal counting was performed in CA3 between the black lines indicated in $\boldsymbol{A}$ and $\boldsymbol{B}$. C, Quantification of NeuNpositive neurons in the $C A 3$ region of the hippocampus by stereological counting showed a significant reduction in $A P P ; C 3^{-/-}$mice (filled bars) compared with APP mice (open bars) $\left({ }^{*} p<0.05\right)$. No difference in neuronal counts was detected between $\mathrm{APP}$ and $\mathrm{APP} ;\left(3^{-1-}\right.$ mice at 12 months of age. A significant reduction in neurons was observed in $A P P ; C 3^{-1-}$ mice, but not APP mice, from 12 to 17 months of age ( $p=0.015$ ). $\boldsymbol{D}$, The number of NeuN-positive neurons of individual mice correlated significantly with their thioflavin $S$ plaque load $(r=$ $-0.636 ; p<0.05 ; n=5$ mice per group; open diamonds indicate APP mice, and black circles indicate $A P P, C 3^{-1-}$ mice). $\boldsymbol{E}, \mathrm{MAP2}$ immunoreactivity was nonsignificantly reduced in complement C3-deficient APP mice compared with complement-sufficient APP mice. $\boldsymbol{F}$, Synaptophysin levels in TBS-T extracts of brain homogenate were nonsignificantly reduced in APP; $\mathrm{C}^{-1-}$ mice by Western blot compared with APP mice. Scale bar, $100 \mu \mathrm{m}$.

APP transgenic mice, in general. However, these trends provide additional support to the overall findings.

The rather late effect of C3 deficiency may be related to an attempt of APP mice to protect the brain by upregulating complement C3 once AD-like pathogenesis is underway. Similar to a previous report by Wyss-Coray et al. (2002), we observed an increase in $\mathrm{C} 3$ protein levels with aging and $\mathrm{AD}$ pathogenesis in APP mice. In their study, Wyss-Coray and colleagues demonstrated that $\mathrm{C} 3 \mathrm{mRNA}$ levels increased with age in APP mice and that C3 protein levels were elevated when TGF- $\beta$ was overexpressed in APP mice (Wyss-Coray et al., 2002). Inhibition of complement C3 convertase (to block activation of C3) by overexpression of sCrry in APP mice resulted in increased plaque burden and neurodegeneration, even in the presence of $\mathrm{C} 3$ protein (Wyss-Coray, 2002).

Consistent with an important role of complement in latestage AD-like pathogenesis is a study (Matsuoka et al., 2001) showing the colocalization of complement-activating $\mathrm{Clq}$ and an upregulation of $\mathrm{C} 1 \mathrm{q}$ with increased formation of fibrillar $\mathrm{A} \beta$ plaques in a PS1/APP transgenic mouse model. In addition, we reported previously prominent $\mathrm{C} 1 \mathrm{q}$ and $\mathrm{C} 3$ immunoreactivity in highly compacted $\mathrm{A} \beta_{42}$-positive neuritic plaques associated with microgliosis in the cortex of middle-aged and older individuals with Down syndrome (Stoltzner et al., 2000). Whether the elevation of complement proteins in $\mathrm{AD}$ brain is an attempt to protect the brain or a consequence of neuronal damage is unclear, but our results, along with those of Wyss-Coray et al. (2002), suggest that complement C3 may play a protective role in the brain.

Amyloid fibrils have been detected in microglia in human $\mathrm{AD}$ brain, suggesting that microglia are involved in the clearing of $\mathrm{A} \beta$ protein deposits (Wegiel and Wisniewski, 1990). Furthermore, it has also been shown in multiple studies that different forms of aggregated $\mathrm{A} \beta$ activate and become bound by complement opsonins such as C3b (Webster et al., 1997; Bradt et al., 1998), which facilitates CR3-mediated phagocytosis of A $\beta$ (Ehlers, 2000). Recent mouse studies report a reduction in the microglial markers F4/80 and major histocompatibility complex class II alloantigens, I-A/I-E, in old C1q-deficient Tg2576 (APP) transgenic mice (Fonseca et al., 2004). In addition, F4/80-positive microglia were reduced in APP/sCrry mice (Wyss-Coray et al., 2002). By Western blot, we, too, found a nonsignificant trend for reduced F4/80 as well as CD68 levels in our 17-month-old $A P P ; C 3^{-1-}$ mice. Therefore, it is possible that the increased fibrillar plaque load observed in our C3-deficient APP Tg mice may be attributable to less efficient phagocytosis of $\mathrm{A} \beta$ fibrils in the absence of $\mathrm{C} 3$ attributable to lack of $\mathrm{C} 3 \mathrm{~b}$ - or iC3b-mediated opsonization.

Interestingly, although $\mathrm{F} 4 / 80$ and CD68 levels were reduced in our 17-month-old $A P P ; C 3^{-/-}$mice compared with age-matched APP mice, we found increases in other microglia/macrophage markers of activation, including CD45 (significant) and Iba1 (nonsignificant trend), correlating with increased $\mathrm{A} \beta$ plaque burden and neurodegeneration. C3 deficiency in 17-month-old APP mice resulted in increased IL-4 $(p<0.05$ in TBS-soluble fraction) and IL-10 (nonsignificant trend) and reduced iNOS $(p<0.05)$ and TNF $(p<0.05$ in TBS-T membrane-bound fraction) brain levels. Others have demonstrated that antiinflammatory cytokines, such as IL-4 and IL-10, increased fibrillar $\mathrm{A} \beta$ phagocytosis by murine primary microglia in vitro (Koenigsknecht-Talboo and Landreth, 2005). Although antiinflammatory cytokine levels were elevated in the $A P P ; C 3^{-1-}$ mice in our study, $A \beta$ deposition was increased as well, indicating that $\mathrm{A} \beta$ phagocytosis by microglia was ineffective at removing $\mathrm{A} \beta$ deposits. Thus, it is possible that the presence of complement C3 may be necessary for anti-inflammatory cytokines to stimulate microglial phagocytosis of aggregated $\mathrm{A} \beta$.

Together, our findings indicate a shift of the microglia/macrophage response toward an alternative $\mathrm{M} 2$ activation phenotype (Mantovani et al., 2004; Morgan et al., 2005) in the absence of complement C3. M2-type microglia/macrophage are often found in association with apoptotic cells to scavenge debris and promote tissue repair, which is in agreement with the increased neurodegeneration we observed in the 17 -month-old $A P P ; C 3^{-1-}$ mice. Upregulation of CD45, which is expressed at high levels in infiltrating microglia/macrophage (Ford et al., 1995), could represent enhanced infiltration of peripheral macrophages attributable to increased fibrillar $\mathrm{A} \beta$ deposits and a higher incidence of dying cells in brain. It should be noted that, in the study of WyssCoray et al. (2002), inhibition of C3 convertase by sCrry overexpression may have only affected certain microglial functions such as $\mathrm{A} \beta$ phagocytosis, whereas the complete absence of $\mathrm{C} 3$ may have additional affects on microglial function and/or molecules that normally suppress microglial activation along the phagocytic and cytotoxic pathways. Ours is the first study to fully examine 
the role of complement $\mathrm{C} 3$ on the microglia/macrophage phenotype and cytokines in APP mice.

Alternatively, increased $\mathrm{A} \beta$ deposition in brain and $\mathrm{A} \beta$ levels in plasma in C3-deficient APP Tg mice may also be attributable to reduced peripheral degradation of $A \beta$. Indeed, a recent study suggested an important role of complement C3 in the peripheral clearance of $\mathrm{A} \beta$ by $\mathrm{C} 3 \mathrm{~b}$-dependent adherence to CR1 on erythrocytes in blood of humans (Rogers et al., 2006). A recently described complement receptor, CR1g, was found to be important for C3b-dependent clearance of pathogens from the blood (Helmy et al., 2006) and, thus, may represent an additional pathway for clearance of complement-opsonized A $\beta$ in the periphery. Such a mechanism should be affected in C3-deficient APP mice. Indeed, the absence of $\mathrm{C} 3$ resulted in the accumulation of $A \beta$ in the periphery, thereby increasing the amount of peripheral $A \beta$ available for influx into the brain.

In contrast to guanidine-soluble $\mathrm{A} \beta_{42}$ levels, which were increased with the fibrillar $\mathrm{A} \beta$ plaque load, TBS-soluble and to some extent also TBS-T-soluble $A \beta$ levels were reduced in the brains of C3-deficient APP mice. Therefore, it is possible that complement $\mathrm{C} 3$ also plays a role in suppressing aggregation of $\mathrm{A} \beta$, in which case the lack of $\mathrm{C} 3$ would result in reduced soluble $\mathrm{A} \beta$ levels in brain and increased deposition of aggregated $\mathrm{A} \beta$ into plaques. However, this seems unlikely because C3 levels were elevated in the complement-sufficient APP Tg mice with age as $\mathrm{A} \beta$ became more aggregated.

Increased amounts of fibrillar $\mathrm{A} \beta$ deposition in 17-month-old $A P P ; C 3^{-1-}$ mice correlated with a reduction of NeuN-positive neurons in hippocampus, suggesting a role for complement $\mathrm{C} 3$ in neuronal survival and health. Neuronal loss was highest in CA3 compared with CA1, possibly attributable to increased hAPP transgene expression and $A \beta$ deposition. Neurons express C3; thus, the neurons in C3-deficient APP mice may be more vulnerable to the cytotoxic effects of $\mathrm{A} \beta$ and/or microglial activation. However, C3-deficient neurons in 12-month-old $A P P ; C 3^{-1-}$ mice appeared relatively healthy. MAP2 and synaptophysin immunoreactivity were nonsignificantly reduced in $A P P ; C 3^{-1-}$ mice, in agreement with the findings of Wyss-Coray et al. (2002) in which a similar neuronal phenotype was observed during inhibition of C3 convertase. By electron microscopy, they reported an accumulation of degenerating neurons in APP/sCrry mice compared with wild-type mice that correlated with the reduction of NeuN-positive neurons. Our findings agree with other studies that have proposed a neuroprotective effect of complement proteins and complement activation products such as $\mathrm{C} 3 \mathrm{a}$ and $\mathrm{C} 5 \mathrm{a}$ (van Beek et al., 2003).

A recent study attributes an important role to complement $\mathrm{C} 3$ and its receptor $\mathrm{C} 3 \mathrm{aR}$ in basal- and ischemia-induced neurogenesis in young adult mice (Rahpeymai et al., 2006). The reduction of NeuN-positive neurons in $A P P ; C 3^{-/-}$mice may be attributable to a reduction of neurogenesis over the lifespan of C3deficient mice. However, because the average number of hippocampal CA3 NeuN-positive neurons per section was similar in 12 -month-old $A P P ; C 3^{-/-}$versus APP mice, this seems unlikely. Quantification of DCX-positive cells in the GCL of the dentate gyrus, the source for new hippocampal neurons, was not possible because the DCX staining in GCL was below detectable levels in the 12- and 17-month-old APP and APP;C $3^{-1-}$ mouse brain sections (in contrast to DCX-positive cell clusters in the SVZ), consistent with previous reports in APP mice (Jin et al., 2004).

In addition, $\mathrm{C} 1 \mathrm{q}$ and $\mathrm{C} 3$ were recently reported to play a role in CNS synapse elimination as shown by the failure of C1qdeficient and C3-deficient mice to fully refine retinogeniculate connections during postnatal development (Stevens et al., 2007). Complement-independent mechanisms of synapse elimination may also exist (as suggested by the authors) and may have allowed synapse elimination during development in our $A P P ; C 3^{-1-}$ mice. Furthermore, initial studies in a glaucoma mouse model by the same group suggest that complement-mediated synapse elimination may become aberrantly reactivated under disease conditions via upregulation of $\mathrm{Clq}$ at the synapse, leading to synaptic and neuronal degeneration. The presence and possible upregulation of complement $\mathrm{Clq}$ in our $A P P ; C 3^{-/-}$mice with aging may have contributed to the synapse reduction and neuronal loss we observed at 17 months of age.

In summary, we demonstrate that C3 deficiency in APP mice resulted in increased cerebral $\mathrm{A} \beta$ deposition and neuronal loss as well as a shift to a M2 microglial/macrophage response, thereby supporting a beneficial, neuroprotective role of complement C3 in brain. Additional studies are underway to further tease apart the various mechanisms by which complement proteins influence neuronal health at different ages.

\section{References}

Bradt BM, Kolb WP, Cooper NR (1998) Complement-dependent proinflammatory properties of the Alzheimer's disease beta-peptide. J Exp Med 188:431-438.

Ehlers MR (2000) CR3: a general purpose adhesion-recognition receptor essential for innate immunity. Microbes Infect 2:289-294.

Eikelenboom P, Hack CE, Rozemuller JM, Stam FC (1989) Complement activation in amyloid plaques in Alzheimer's dementia. Virchows Arch B Cell Pathol Incl Mol Pathol 56:259-262.

Fonseca MI, Zhou J, Botto M, Tenner AJ (2004) Absence of C1qleads to less neuropathology in transgenic mouse models of Alzheimer's disease. J Neurosci 24:6457-6465.

Ford AL, Goodsall AL, Hickey WF, Sedgwick JD (1995) Normal adult ramified microglia separated from other central nervous system macrophages by flow cytometric sorting. Phenotypic differences defined and direct ex vivo antigen presentation to myelin basic protein-reactive CD4 $+\mathrm{T}$ cells compared. J Immunol 154:4309-4321.

Gasque P, Fontaine M, Morgan BP (1995) Complement expression in human brain. Biosynthesis of terminal pathway components and regulators in human glial cells and cell lines. J Immunol 154:4726-4733.

Helmy KY, Katschke Jr KJ, Gorgani NN, Kljavin NM, Elliott JM, Diehl L, Scales SJ, Ghilardi N, van Lookeren Campagne M (2006) CRIg: a macrophage complement receptor required for phagocytosis of circulating pathogens. Cell 124:915-927.

Irizarry MC, Soriano F, McNamara M, Page KJ, Schenk D, Games D, Hyman BT (1997) A $\beta$ deposition is associated with neuropil changes, but not with overt neuronal loss in the human amyloid precursor protein V717F (PDAPP) transgenic mouse. J Neurosci 17:7053-7059.

Jin K, Galvan V, Xie L, Mao XO, Gorostiza OF, Bredesen DE, Greenberg DA (2004) Enhanced neurogenesis in Alzheimer's disease transgenic (PDGF-APPSw, Ind) mice. Proc Natl Acad Sci USA 101:13363-13367.

Johnson-Wood K, Lee M, Motter R, Hu K, Gordon G, Barbour R, Khan K, Gordon M, Tan H, Games D, Lieberburg I, Schenk D, Seubert P, McConlogue L (1997) Amyloid precursor protein processing and A beta42 deposition in a transgenic mouse model of Alzheimer disease. Proc Natl Acad Sci USA 94:1550-1555.

Koenigsknecht-Talboo J, Landreth GE (2005) Microglial phagocytosis induced by fibrillar $\beta$-amyloid and IgGs are differentially regulated by proinflammatory cytokines. J Neurosci 25:8240-8249.

Larsson E, Lindvall O, Kokaia Z (2001) Stereological assessment of vulnerability of immunocytochemically identified striatal and hippocampal neurons after global cerebral ischemia in rats. Brain Res 913:117-132.

Lemere CA, Spooner ET, Leverone JF, Mori C, Clements JD (2002) Intranasal immunotherapy for the treatment of Alzheimer's disease: Escherichia coli LT and LT(R192G) as mucosal adjuvants. Neurobiol Aging 23:991-1000.

Lemere CA, Spooner ET, LaFrancois J, Malester B, Mori C, Leverone JF, Matsuoka Y, Taylor JW, DeMattos RB, Holtzman DM, Clements JD, Selkoe DJ, Duff KE (2003) Evidence for peripheral clearance of A $\beta$ fol- 
lowing chronic, active $\mathrm{A} \beta$ immunization in PSAPP mice. Neurobiol Dis 14:10-18.

Lévi-Strauss M, Mallat M (1987) Primary cultures of murine astrocytes produce $\mathrm{C} 3$ and factor $\mathrm{B}$, two components of the alternative pathway of complement activation. J Immunol 139:2361-2366.

Lledo PM, Alonso M, Grubb MS (2006) Adult neurogenesis and functional plasticity in neuronal circuits. Nat Rev Neurosci 7:179-193.

Maier M, Seabrook TJ, Lemere CA (2005) Modulation of the humoral and cellular immune response in Abeta immunotherapy by the adjuvants monophosphoryl lipid A (MPL), cholera toxin B subunit (CTB) and E. coli enterotoxin LT(R192G). Vaccine 23:5149-5159.

Maier M, Seabrook TJ, Lazo ND, Jiang L, Das P, Janus C, Lemere CA (2006) Short amyloid- $\beta(A \beta)$ immunogens reduce cerebral $A \beta$ load and learning deficits in an Alzheimer's disease mouse model in the absence of an $A \beta$ specific cellular immune response. J Neurosci 26:4717-4728.

Mantovani A, Sica A, Sozzani S, Allavena P, Vecchi A, Locati M (2004) The chemokine system in diverse forms of macrophage activation and polarization. Trends Immunol 25:677-686.

Matsuoka Y, Picciano M, Malester B, LaFrancois J, Zehr C, Daeschner JM, Olschowka JA, Fonseca MI, O’Banion MK, Tenner AJ, Lemere CA, Duff K (2001) Inflammatory responses to amyloidosis in a transgenic mouse model of Alzheimer's disease. Am J Pathol 158:1345-1354.

McGeer PL, McGeer EG (2002) The possible role of complement activation in Alzheimer disease. Trends Mol Med 8:519-523.

McGeer PL, Akiyama H, Itagaki S, McGeer EG (1989) Activation of the classical complement pathway in brain tissue of Alzheimer patients. Neurosci Lett 107:341-346.

Morgan D, Gordon MN, Tan J, Wilcock D, Rojiani AM (2005) Dynamic complexity of microglial activation response in transgenic models of amyloid deposition: implications for Alzheimer's therapeutics. J Neuropathol Exp Neurol 64:743-753.

Mucke L, Masliah E, Yu GQ, Mallory M, Rockenstein EM, Tatsuno G, Hu K, Kholodenko D, Johnson-Wood K, McConlogue L (2000) High-level neuronal expression of $\mathrm{A} \beta_{1-42}$ in wild-type human amyloid protein precursor transgenic mice: synaptotoxicity without plaque formation. J Neurosci 20:4050-4058.

Mullen RJ, Buck CR, Smith AM (1992) NeuN, a neuronal specific nuclear protein in vertebrates. Development 116:201-211.

Osaka H, Mukherjee P, Aisen PS, Pasinetti GM (1999) Complementderived anaphylatoxin C5a protects against glutamate-mediated neurotoxicity. J Cell Biochem 73:303-311.

Pasinetti GM, Tocco G, Sakhi S, Musleh WD, DeSimoni MG, Mascarucci P, Schreiber S, Baudry M, Finch CE (1996) Hereditary deficiencies in complement $\mathrm{C} 5$ are associated with intensified neurodegenerative responses that implicate new roles for the C-system in neuronal and astrocytic functions. Neurobiol Dis 3:197-204.

Peng Y, Jiang L, Lee DY, Schachter SC, Ma Z, Lemere CA (2006) Effects of huperzine A on amyloid precursor protein processing and beta-amyloid generation in human embryonic kidney 293 APP Swedish mutant cells. J Neurosci Res 84:903-911.

Rahpeymai Y, Hietala MA, Wilhelmsson U, Fotheringham A, Davies I, Nilsson AK, Zwirner J, Wetsel RA, Gerard C, Pekny M, Pekna M (2006) Complement: a novel factor in basal and ischemia-induced neurogenesis. EMBO J 25:1364-1374.
Rogers J, Li R, Mastroeni D, Grover A, Leonard B, Ahern G, Cao P, Kolody H, Vedders L, Kolb WP, Sabbagh M (2006) Peripheral clearance of amyloid beta peptide by complement C3-dependent adherence to erythrocytes. Neurobiol Aging 27:1733-1739.

Shen Y, Li R, McGeer EG, McGeer PL (1997) Neuronal expression of mRNAs for complement proteins of the classical pathway in Alzheimer brain. Brain Res 769:391-395.

Stevens B, Allen NJ, Vazquez LE, Howell GR, Christopherson KS, Nouri N, Micheva KD, Mehalow AK, Huberman AD, Stafford B, Sher A, Litke AM, Lambris JD, Smith SJ, John SW, Barres BA (2007) The classical complement cascade mediates CNS synapse elimination. Cell 131:1164-1178.

Stoltzner SE, Grenfell TJ, Mori C, Wisniewski KE, Wisniewski TM, Selkoe DJ, Lemere CA (2000) Temporal accrual of complement proteins in amyloid plaques in Down's syndrome with Alzheimer's disease. Am J Pathol 156:489-499.

Terai K, Walker DG, McGeer EG, McGeer PL (1997) Neurons express proteins of the classical complement pathway in Alzheimer disease. Brain Res 769:385-390.

Thomas A, Gasque P, Vaudry D, Gonzalez B, Fontaine M (2000) Expression of a complete and functional complement system by human neuronal cells in vitro. Int Immunol 12:1015-1023.

van Beek J, Elward K, Gasque P (2003) Activation of complement in the central nervous system: roles in neurodegeneration and neuroprotection. Ann NY Acad Sci 992:56-71.

Webster S, Bradt B, Rogers J, Cooper N (1997) Aggregation state-dependent activation of the classical complement pathway by the amyloid beta peptide. J Neurochem 69:388-398.

Wegiel J, Wisniewski HM (1990) The complex of microglial cells and amyloid star in three-dimensional reconstruction. Acta Neuropathol 81:116-124.

Wessels MR, Butko P, Ma M, Warren HB, Lage AL, Carroll MC (1995) Studies of group B streptococcal infection in mice deficient in complement component $\mathrm{C} 3$ or $\mathrm{C} 4$ demonstrate and essential role for complement in both innate and acquired immunity. Proc Natl Acad Sci USA 92:490-494.

West MJ, Gundersen HJ (1990) Unbiased stereological estimation of the number of neurons in the human hippocampus. J Comp Neurol 296:122.

Wilcock DM, Alamed J, Gottschall PE, Grimm J, Rosenthal A, Pons J, Ronan V, Symmonds K, Gordon MN, Morgan D (2006) Deglycosylated antiamyloid- $\beta$ antibodies eliminate cognitive deficits and reduce parenchymal amyloid with minimal vascular consequences in aged amyloid precursor protein transgenic mice. J Neurosci 26:5340-5346.

Wyss-Coray T, Lin C, Yan F, Yu GQ, Rohde M, McConlogue L, Masliah E, Mucke L (2001) TGF-betal promotes microglial amyloid-beta clearance and reduces plaque burden in transgenic mice. Nat Med 7:612-618.

Wyss-Coray T, Yan F, Lin AH, Lambris JD, Alexander JJ, Quigg RJ, Masliah E (2002) Prominent neurodegeneration and increased plaque formation in complement-inhibited Alzheimer's mice. Proc Natl Acad Sci USA 99:10837-10842.

Yasojima K, Schwab C, McGeer EG, McGeer PL (1999) Up-regulated production and activation of the complement system in Alzheimer's disease brain. Am J Pathol 154:927-936. 